\title{
Does countries' environmental, social and governance (ESG) risk rating influence international tourism demand? A case of the Visegrád Four
}

\author{
Adewale Samuel Hassan and Daniel Francois Meyer
}

\begin{abstract}
Purpose - This study examines whether international tourism demand in the Visegrád countries is influenced by countries' risk rating on environmental, social and governance (ESG) factors, as non-economic factors relating to ESG risks have been ignored by previous researches on determinants of international tourism demand.

Design/methodology/approach - The study investigates panel data for the Visegrád countries comprising the Czech Republic, Hungary, Poland and Slovakia over the period 1995-2019. Recently developed techniques of augmented mean group (AMG) and common correlated effects mean group (CCEMG) estimators are employed so as to take care of cross-sectional dependence, nonstationary residuals and possible heterogeneous slope coefficients.

Findings - The regression estimates suggest that besides economic factors, the perception of international tourists regarding ESG risk is another important determinant of international tourism demand in the Visegrád countries. The study also established that income levels in the tourists' originating countries are the most critical determinant of international tourism demand to the Visegrád countries.

Originality/value - The research outcomes of the study include the need for the Visegrád countries to direct policies towards further mitigating their ESG risks in order to improve future international tourism demand in the area. They also need to ensure exchange rate stability to prevent volatility and sudden spikes in the relative price of tourism in their countries.
\end{abstract}

Keywords Future tourism demand, ESG risk Rating, Visegrád, AMG, Cross-sectional dependence, Cointegration

Paper type Research paper

\section{Introduction}

International tourism has over the years been considered as an important driver of socio-economic development, especially considering its massive potential in increasing the per capita income, attracting foreign investment, generating tax revenues, creating jobs, accelerating infrastructural development, enhancing foreign reserves and fostering the understanding of different cultures and geographical dynamics across the globe (Habibi, 2017; Jalil et al., 2013; Tang and Abosedra, 2014; Balcilar et al., 2014; UNWTO, 2019). Notably, the development of tourism has been identified in the literature as one of the surest ways to enhance economic growth, reduce poverty, drive investment, create employment opportunities and improve the living standard of the people in the economy (Akadiri et al., 2017; Balli et al., 2019; Du et al., 2016; Pratt, 2015; Rasekhi et al., 2016; Roudi et al., 2018; Tang and Tan, 2015).
Adewale Samuel Hassan and Daniel Francois Meyer are both based at the College of Business and Economics, University of Johannesburg, Auckland Park, South Africa.

Received 24 May 2021 Revised 5 December 2021 Accepted 14 January 2022

(C) Adewale Samuel Hassan and Daniel Francois Meyer. Published in Journal of Tourism Futures. Published by Emerald Publishing Limited. This article is published under the Creative Commons Attribution (CC BY 4.0) licence. Anyone may reproduce, distribute, translate and create derivative works of this article (for both commercial and non-

commercial purposes), subject to full attribution to the original publication and authors. The full terms of this licence may be seen at http://creativecommons.org/ licences/by/4.0/legalcode. 
At the global level, the tourism sector has continued to expand astronomically over the last 50 years, so much so that the number of international tourist destinations earning a minimum of US\$1 billion has almost doubled in 2019, compared to 1998. In 2019, international tourist arrivals of 1.5 billion were recorded, representing a 4\% increase in the figures for 2018 and a significant improvement on the 1.04 billion tourist arrivals for 2012 (UNWTO, 2020). Also, underscoring the tourism sector as a truly global and resilient force for promoting economic growth and development is the export earnings from tourism which grew to US\$1.7 trillion in 2019 (UNWTO, 2020). Furthermore, according to Travel and Tourism Economic Impact (2017), the tourism industry was responsible for $10.2 \%$ of the global GDP (which amounted to US\$7.6 trillion) in 2016, while also in the same year, one out of every ten jobs in the world was generated in the tourism sector, amounting to 292 million jobs. This achievement by the tourism sector lends credence to the forecast of the World Economic Forum (2013) regarding the future of tourism that by 2023, the tourism industry would account for about 10.3\% of global GDP and generate about 346 million jobs. COVID-19 has, however, affected all forecasting and tourism activities have been severely affected by the pandemic.

In the last two decades, the tourism industry has gained increased prominence in the four Central European sovereign states, known as the Visegrád Four (V4), which comprise the Czech Republic, Hungary, Poland and Slovakia. According to Czech Tourism (2017), the sector's contributions to GDP in 2016 were 6.1\%, 2.5\% and 2.7\% for the Czech Republic, Hungary and Slovakia. The number of tourist arrivals for each country has also continued to increase significantly to 18.4 million (the Czech Republic), 11.1 (Hungary), 29 million (Poland) and 5 million (Slovakia) in 2016, while tourism receipts in the countries in 2016 were $€ 5.2$ billion (the Czech Republic), $€ 5.1$ billion (Hungary), $€ 13.2$ billion (Poland) and $€ 2.4$ billion (Slovakia), reflecting significant improvements in the tourism numbers since 2012 (Czech Tourism, 2017). In recognition of the pivotal role and enormous potential of tourism in the socio-economic development of the four Central European economies and in a bid to revolutionize the industry towards increased visibility in the future, the V4 established a joint tourism campaign, referred to as "Discovery Central Europe". The promotional name for the joint tourism campaign is "European Quartet", and the sole aim is to promote international tourism (especially tourists from outside Europe) to the four countries. The V4 share both historical roots and cultural traditions and boast many unique heritage sites, UNESCO monuments, authentically preserved historical towns, world-famous spas, as well as a good number of individual country's unique landscape or traditions and also identity and endowments in the fields of architecture, art, religion and folklore (Hungarian Central Statistical Office, 2018). The existence of these tourism-oriented features do indeed portend huge potentials for the future of international tourism demand to the $\mathrm{V} 4$, especially if they are promoted to the global market.

The massive contribution of the tourism industry to the socio-economic development of the V4 over the years necessitates a detailed investigation of the underlying factors that influence tourism demand in the area, given its global and highly competitive nature and in the face of the currently ravaging coronavirus COVID-19 pandemic which has resulted in border closures and travel restrictions across the world, leading to a plunge in international tourist arrivals by $74 \%$ in 2020 , which amounted to 1 billion fewer international arrivals (UNWTO, 2021). The demand for tourism has been extensively investigated over the years, with much earlier studies concerned with issues that relate to the measurement of variables such as identifying adequate explanatory variables, conceptualising variables and identifying appropriate proxies for them (e.g. Morley, 1994; Uysal and Crompton, 1985; Witt and Martin, 1987), while many studies in recent times tend to explore issues that relate to modelling and forecasting, as well as the levels of data (Dogru et al., 2017; Eugenio-Martin, 2003; Morley et al., 2014; Surugiu et al. , 2011). One notable feature in the majority of past studies on the demand for tourism is the prevalence of emphasis on economic factors such as relative price, income, exchange rate, trade and travel cost (Abedtalas and Topras, 2015; De Vita, 2014; Leitão, 2010; Martins et al. , 2017; Seetanah et al., 2010; Shafiullah et al. , 2018; Surugiu et al. , 2011; Takahashi, 2020; Tavares and Leitão, 2017). In addition to the fact that researchers are yet to agree on shared factors that influence the demand for tourism (Peng et al., 2014), noneconomic factors relating to environmental, social and governance issues are seldom considered 
by researchers in their investigation. This brings into question whether tourists consider factors other than the aforementioned economic factors, in making decisions about their future tourism plans. Specifically, we seek to investigate whether the extra-economic performance of the $\mathrm{V} 4$ on environmental, social and governance (ESG) risks matter for demand for international tourism to the four countries. According to the CountryRisk.io (2020), the environmental factors include issues of climate change, water resources and pollution, biodiversity, energy resources and management, air pollution, natural disasters, bio-capacity and ecosystem quality and natural resources, while social factors comprise issues of human rights, health levels, political freedoms, food security, social exclusion and poverty, crime and safety and trust in society/institutions. The governance factors consist of corruption, regime stability, the rule of law, accounting standards, regulatory effectiveness and quality, institutional strength, political rights and civil liberties and government finances.

The literature supporting the notion that a country's ESG risk performance could impact the demand for international tourism is predicated on tourists' perception of the country's tourism market based on the adjudged level of risk on the abovementioned ESG factors. Theoretically, ESG performance measures how well a country can address and mitigate environmental, social and governance-related risks (Crifo et al., 2017), and going by the highly competitive nature of the tourism market, little differences in ESG related risks among countries may likely exert an immense impact on international tourists' demand, as tourists may become wary of destinations with less favourable ESG risk ratings. Thus, we are motivated to investigate the role of ESG countries' risk rating in explaining tourism demand based on the literature regarding the impact of each component on tourism. For example, the climate has been identified as an important determinant of tourism demand (Berrittella et al., 2006; UNWTO, 2003), as tourists in search of a relaxed atmosphere tend to favour countries with sunny and snowy climate (Aguiló et al., 2005; Gössling and Hall, 2006), while Hamilton et al. (2005) argued that tourists might favour extraordinary destinations owing to the effects of global warming. It has also been argued that tourism could be very unstable and highly sensitive to undesirable environmental and social issues such as seasonality, terrorism, natural disasters, epidemics and political unrest (Cothran and Cothran, 1998; Hall and O'Sullivan, 1996; Ridderstaat et al., 2014; UNCTAD, 2013). In recent years, researchers have also explored the role of social factors such as security, peacefulness, crime, territorial integrity of countries, political stability, terrorism, domestic violence, civil conflict and institutions, on tourism demand, with a preponderance of findings that negative social factors depress demand for international tourism (Ballia et al., 2018; Demir and Gozgor, 2018; Edgell et al., 2013; Kim et al., 2018; Thompson, 2011; Yap and Saha, 2013). Furthermore, it has been documented that tourists tend to avoid destinations with poor governance in favour of less attractive destinations, but which have good governance (Araña and León, 2008; Ghalia et al., 2019; Lee et al., 2020; Pizam and Mansfeld, 2006). The military's incursion into politics has also been established as a significant source of hindrance to the future of tourism (Khalid et al., 2019; Saha and Yap, 2014).

Against this background, we raise the question of the impact of ESG countries' risk rating on international tourism demand in the Visegrád countries. To the best of the authors' knowledge, this particular subject has not yet been investigated in the literature, not least in the context of the V4. Therefore, this study would contribute to the literature on tourism by shedding light on the response of international tourism demand to changes in the countries' risk rating on ESG factors, with particular reference to the $\mathrm{V} 4$. As such, the study would provide important insight to how the future of tourism industry in the $\mathrm{V} 4$ could be brightened by paying attention to the risks arising from ESG factors. This study also contributes to the literature on tourism demand by accounting for cross-sectional dependence (CSD) in the panel data employed by following the xtmg programmes introduced by Eberhardt (2012), which are formulated to generate estimates for Eberhardt and Teal's (2010) augmented mean group estimator. Previous studies on tourism demand have ignored the issue of CSD among panels of countries, and according to Sadorsky (2013) and Turkay (2017), conventional estimation techniques such as fixed effect, random effect, pooled regression or generalised method of moments estimator, generate invalid estimates when CSD characterises panel data. The need to account for CSD in the current study is critical. It involves a set of countries with a high level of socio-economic interaction, common historical roots and 
cultural traditions, and a level of financial integration. According to De Hoyos and Sarafidis (2006), all these factors engender CSD among economies in the current era of globalisation. Hence, ignoring the issue of CSD in a study involving this set of countries could lead to invalid results.

The rest of the paper is arranged as follows: Section 2 captures overview of ESG risk rating and empirical literature review, while data and methodology are discussed in Section 3. Results are presented and discussed in Section 4, while Section 5 concludes the study.

\section{Literature review}

\subsection{Overview of ESG risk ratings in the assessment of the future of tourism}

The use of ESG risk rating has gained increased prominence in the last 20 years. This is not unconnected with heightened environmental concerns, increased social and governance consciousness that have been observed worldwide. The acronym ESG was officially coined by the UN Global Compact Initiative (UN, 2004), with each of the three-letter word encapsulating specific issues and measuring a particular assessment objective. The environmental pillar is directed towards issues of air pollution, biodiversity, biocapacity and quality of the ecosystem, climate change, energy resources and management, land exploitation, natural disasters and natural resources. Thus, the environmental pillar assesses a country's efforts regarding the control and management of greenhouse gas emissions, waste, water resources, energy consumption and efficiency, etc. As mentioned earlier, the literature has established relationship between environmental performance and international tourism demand (e.g. Berrittella et al., 2006; Hamilton et al., 2005; Usman et al., 2020). The social pillar incorporates issues that concern human rights, food security, public health, demographic change, crime and safety. The link between social pillar issues and tourism potentials have also been established in the literature (Ghalia et al., 2019; Kim et al., 2020; Usman et al., 2020). Lastly, the governance pillar examines a country's efforts at improving corruption control, institutions, rule of law, accountability, political rights and civil liberty. Many studies tend to emphasize the significant positive impact of improvement in these factors on international tourism demand (see Detotto et al., 2021; Saha and Yap, 2014; Tang, 2018).

The need to investigate the relationship between ESG risk rating and international tourism demand is important considering the fact that tourism is included as important targets under the United Nations sustainable development goals (SDGs) 8, 12 and 14: promote inclusive and sustainable economic growth, employment and decent work for all; ensure sustainable consumption and production patterns; and conserve and sustainably use the oceans, seas and marine resources for sustainable development, respectively. Furthermore, efforts towards attracting tourists into a country through construction of tourism facilities could engender the depletion of the ecological footprints with damning consequences on mankind, while in a bid to brighten the international tourism future of their countries, governments have been reported to revolutionize their policies, processes and structures in terms of environmental sustainability, human rights protection and free market (Göymen, 2000). Thus, an assessment of the impact of success or failure in mitigating the ESG risk issues provides important insight on the future of international tourism.

Meanwhile, several specialized rating agencies and institutions play important role in the delivery of ESG risk ratings that are widely used both by potential international tourists to make decisions and by researchers in drawing important inferences. Some of the most important institutions providing data on ESG risk ratings include Bloomberg, CountryRisk.io, ASSET4 by Thomson Reuters, Ethical Investment Research Service, FTSE Russell and Sustainalytics. Though each rating institution continually endeavours to ensure delivery of quality ESG risk rating, because of the complex nature of ESG factors, it has been noted in the literature that there is no convergence among the rating institutions on the definition of ESG, in relation to the characteristics and materiality (Billio et al., 2020; Dorfleitner et al., 2015; Pagano et al., 2018). However, Billio et al. (2020) established that divergence in ESG ratings by different institutions does not have negative impact on the quality of the deliverables of the end users. Therefore, ESG risk rating would gain more prominence and increased credibility, more so, in the discussion on the future of tourism, 
if the rating institutions can have a consensus on the underlying principle to determine the overarching and most relevant variables to be included in the computation of ESG risk ratings.

Furthermore, so far, a generic approach has been widely used for all regions and income groups in arriving at their ESG risk ratings, whereas because of the peculiar characteristics of different regions and income classification of countries of the world, an approach that is context-specific might be more appropriate. It is noteworthy, though, that developing a granular ratings system that incorporates many heterogeneous elements (such as environment, culture, stage of development) for context-specific models can pose conundrums. For example, Thomson Reuters had to abandon its attempts towards developing region-specific environmental models, because of the instability of the estimates, which makes meaningful comparison unachievable (TRCTT, 2013). Therefore, to add value to ESG risk ratings, a framework needs to be developed towards contextspecific-oriented system so as to accommodate some peculiar nuances that are inherent in ESG risks.

Finally, and very importantly, in order to enhance the future value of ESG risk ratings, a blend of both quantitative and qualitative methodology is advocated. Most of the ratings have been found to employ mainly quantitative approaches (Pagano et al., 2018), and the information provided by these quantitative methods are mainly historical (though they help to predict the future) and publicly available information, which may not contain critical soft information that could only be acquired through observation and other qualitative means. Therefore, to enhance the predictability of future ESG ratings, which could in turn improve the quality of future tourism decisions, qualitative methods should be incorporated by the rating institutions.

\subsection{Empirical literature}

Research efforts on demand for tourism have evolved over the years from variable measurement to modelling, forecasting and levels of data (Dogru et al., 2017; Morley, 1994; Morley et al., 2014), with preponderant focus on economic factors. Meanwhile, following numerous mixed findings in the literature, the debate on the determinants of tourism demand can only be described as far from settled (Peng et al. , 2014). Hence the argument that demand for tourism may also depend on noneconomic factors such as environmental, social and governance (ESG) risk factors, which also brings to question how important these risk factors are to the future of tourism. From an empirical view, the link between countries' tourism demand and each facet of their ESG risk performance has been studied in the literature. For instance, on environmental factors, the climate has been an important determinant of tourism demand, as tourists look out for destinations with a relaxed atmosphere (Aguiló et al., 2005; Gössling and Hall, 2006). This finding is strongly supported by Berrittella et al. (2006), who argued that in choosing their destinations, tourists are often highly influenced by the climate of destinations under consideration. The UNWTO (2003), in their Djerba Declaration, also indicated that tourists are generally wary of destinations with a high level of pollution. In the declaration, recognition is given to a bilateral association between $\mathrm{CO}_{2}$ emissions and demand for tourism. This position is reinforced by Hamilton et al. (2005), who claimed that extraordinary destinations might attract more tourists than warm ones due to the effect of global warming. Similarly, in a recent study of Malaysia, Usman et al. (2020) established a negative relationship between environmental pollution and tourism demand, thereby arguing that the quality of the Malaysian environment is key for potential tourists in their choice of the country as future tourism destination.

Regarding social factors, by employing cross-country data, Kim et al. (2020) found that social trust exerts a positive impact on tourism demand across countries. However, their results show that once social trust crosses a certain threshold, more trust may negatively affect tourism development. Similarly, in a study involving 131 tourist origin counties and the top 34 destination countries, Ghalia et al. (2019) identified better institutions and lower risk of conflict in both origin and destination countries as critical drivers of increased tourist flow. Furthermore, from the standpoint of health and security subdivision of social factors, Usman et al. (2020) found a 
negative relationship between crime rate and tourism demand in Malaysia. In the same study, the 9/11 terrorist attack on the USA on 11 September 2001 and the 2003 avian flu epidemics have a negative impact on Malaysia's tourism demand.

Meanwhile, a tourism campaign, known as "Malaysia, Truly Asia", developed to promote international tourism to the country, is found to enhance tourism demand in the study, further affirming the relevance of social factors. These findings are corroborated by extant studies which argued that issues of human rights violation, domestic violence, terrorism and conflict intensity engender low demand for tourism (Hall and O'Sullivan, 1996; Thompson, 2011; Yap and Saha, 2013), while in another study, Leitão (2010) identified issues bothering on bilateral trade, immigration, border and geographical distance between Portugal and countries of tourists as the principal factors driving international tourism into the country. The relevance of governance factors in the development of the tourism industry has also been examined in the literature. In a recent study by Detotto et al. (2021) who classified 100 countries according to tourism takings and aggregate score in World Governance Indicators (WGl) governance rating, results from the study suggests a positive correlation between good governance and tourism output, as countries in the lowest distribution of WGI have the lowest tourism output, while countries with higher WGI record high average tourism output. In another cross-country study by Saha and Yap (2014), political instability emanating from autocratic regimes has been named a severe barrier to demand in tourism. Furthermore, by using panel data for 45 tourism origin countries to Malaysia, Tang (2018) found that international tourists are susceptible to issues that relate to government effectiveness, corruption, laws, regulations and political stability.

\section{Methodology}

\subsection{Theoretical framework and data}

As a way of modelling and understanding the demand function for inbound tourism to the V4, the theoretical framework of this study is developed based on the widely used theory of consumer behaviour in line with extant studies (see Habibi, 2017; Tang, 2018; Tang and Lau, 2017; Tang and Tan, 2016). The theory of consumer behaviour refers to the branch of microeconomic theory that focusses on "the process by which individual economic units decide whether, what, when, where, how, and from whom to purchase goods and services" (Walters, 1974). Therefore, the theory encapsulates the factors that determine all the behaviour that consumers display in their search, acquisition, assessment and disposal of goods and services, with the ultimate aim of maximising their utility (Schiffman and Kanuk, 1997). The theory of consumer behaviour state the main factors that influence the demand for consumer goods as price of the goods, income of consumers, price of substitute/complement goods, as well as other factors which include taste and preferences, weather condition, habit, expectations, etc. (Friedman, 1949). The demand for international tourism encompasses the set of goods and services that international tourists purchase in the course of their visit in the host country. Usually, the literature modelling demand for tourism explores the various factors that influence tourism demand (Witt and Martin, 1987). Hence, just as the theory of consumer behaviour fosters the understanding and forecasting of consumer future demands, it constitutes a useful framework for modelling and comprehending future demand for international tourism. Therefore, based on the theory of consumer behaviour, the demand function for international tourism to the V4 can be expressed as:

$$
T D_{i t}=\beta_{0} Y_{i t}^{\beta_{1}} P_{i t}^{\beta_{2}} Z_{i t}^{\theta}
$$

Based on equation (1), demand for international tourism in the $\mathrm{V} 4$ is a function of tourists' income $(Y)$, price of tourism in the $\mathrm{V} 4(P)$ and a vector of other factors that influence international tourism demand $(Z)$. The international tourism demand in V4 (TD) is measured by the total number of international tourist arrivals and the total number of international tourism receipts. Tourists' income $(Y)$ is represented by World real gross domestic product (GDP) per capita, while relative prices represent the price of tourism in the V4. With particular reference to the main objective of this study, the vector of

PAGE 6 | JOURNAL OF TOURISM FUTURES $\mid$ VOL. $\mathbf{m}$ NO. $\mathbf{m}$ 
other factors that influence tourism demand tourists' income ( $Z$ ) comprises countries' ESG risk rating, trade openness and infrastructure. In order to ensure that important variables are not left out in the model, the abovementioned destination factor variables have been selected after careful consideration of the literature in terms of variables that have been established as major determinants of international tourism demand as articulated in the extant literature (see e.g. De Vita, 2014; Detotto et al., 2021; Habibi, 2017; Martins et al., 2017; Seetanah et al., 2010; Shafiullah et al., 2018; Takahashi, 2020; Tang, 2018; Tang and Lau, 2017; Tang and Tan, 2016; Tavares and Leitao, 2017; Usman et al., 2020). Moreover, the inclusion of country-specific effect in the econometric model (see equation (7) in Section 3.4) serves to mitigate the effect of any omitted variables bias that might arise due to non-inclusion of any important variable (Wooldridge, 2010).

To enable estimation, equation (1) is transformed into an econometric model as follows:

$$
\text { In } T D_{i t}=\beta_{0}+\beta_{1} \ln G D P_{i t}+\beta_{2} \ln E R_{i t}+\theta_{1} \ln E S G_{i t}+\theta_{2} \ln T O P_{i t}+\theta_{3} \ln / N F_{i t}+\varepsilon_{t}
$$

The variables in equation (2) are expressed logarithmically because linearizing the parameters of equation (1), being a Cobb-Douglas utility function characterised by diminishing marginal rates of substitution, requires taking its natural logarithm. Moreover, it is also necessary to minimise the likelihood of heteroscedasticity and standardise the variables' unit of measurement (Ejemeyovwi et al., 2018; Uusitalo, 2012).

This study employs annual data from 1995 to 2019 for the V4 comprising the Czech Republic, Hungary, Poland and Slovakia. Table 1 shows the details of the variables, their definitions and sources.

\subsection{Unit root and cross-sectional dependence tests}

In recent time, a growing body of literature has brought to the front burner the issue of crosssectional dependence (CSD) in panel data models due to them being characterised by unobserved components and common shocks (Pesaran, 2004). This problem has become more severe in recent time due to increased globalisation that has necessitated greater interaction and financial integration among economies (De Hoyos and Sarafidis, 2006). One significant implication of the presence of CSD in panel data is that it renders the results of the first-generation unit root tests

\section{Table 1 Definition of variables and sources}

\begin{tabular}{|c|c|c|c|}
\hline No. & Variable & Definition & Source \\
\hline 1. & $\begin{array}{l}\text { International tourism } \\
\text { demand (TD) }\end{array}$ & $\begin{array}{l}\text { (a) Total number of international tourist arrivals } \\
\text { (b) Total amount of international tourism receipts } \\
\text { (current US\$) }\end{array}$ & $\begin{array}{l}\text { World Development } \\
\text { Indicators }\end{array}$ \\
\hline 2. & ESG risk rating & $\begin{array}{l}\text { Countries' ESG risk rating is a composite risk index } \\
\text { comprising environmental, social and governance } \\
\text { (ESG) factors, and it is compiled by CountryRisk.io. } \\
\text { The index measures the level of ESG risk with an } \\
\text { index of } 0.00 \text { indicating the lowest level of risk, while } \\
\text { an index of } 100.00 \text { indicates the highest }\end{array}$ & $\begin{array}{l}\text { https://countryrisk. } \\
\text { io }\end{array}$ \\
\hline 3. & $\begin{array}{l}\text { Tourists' income } \\
\text { (GDP) }\end{array}$ & $\begin{array}{l}\text { World gross domestic product per capita (Constant } \\
2010 \text { USD) as a measure of global income per capita }\end{array}$ & $\begin{array}{l}\text { World Development } \\
\text { Indicators }\end{array}$ \\
\hline 4. & $\begin{array}{l}\text { Relative prices } \\
\text { (REER) }\end{array}$ & $\begin{array}{l}\text { The relative price of tourism is measured by real } \\
\text { effective exchange rate (REER), which is the value of } \\
\text { a currency vis-à-vis a basket of other major } \\
\text { currencies. Therefore, a higher REER results in } \\
\text { exports and/or international tourism becoming more } \\
\text { expensive }\end{array}$ & $\begin{array}{l}\text { World Development } \\
\text { Indicators }\end{array}$ \\
\hline 5. & $\begin{array}{l}\text { Trade openness } \\
\text { (TOP) }\end{array}$ & Total trade as a percentage of GDP & $\begin{array}{l}\text { World Development } \\
\text { Indicators }\end{array}$ \\
\hline 6. & Infrastructure (INFR) & Total number of passengers carried by air transport & $\begin{array}{l}\text { World Development } \\
\text { Indicators }\end{array}$ \\
\hline
\end{tabular}

\begin{tabular}{l|l|l} 
VOL. $\mathbf{m}$ NO. $\boldsymbol{m}$ & JOURNAL OF TOURISM FUTURES & PAGE 7
\end{tabular} 
(such as Im et al., 2003; Levin et al., 2002; Maddala and Wu, 1999) unreliable (Wagner, 2008). This is because this set of tests do not account for CSD in panel data, and as a result, they have often been found to falsely reject the null hypothesis when the panel data is characterised by CSD (Banerjee et al. , 2001). Thus, this study employs the cross-sectionally augmented IPS (CIPS) panel unit root test of Pesaran (2007), which is effectively reputed for its ability to control for CSD in panel data. The CIPS panel unit root test is expressed as follows:

$$
y_{i t}=\rho_{i}+\gamma_{i t} x_{i t}+\varnothing_{i t}
$$

where $i$ and $t$ represent country and time period respectively, while $\gamma_{i t}$ and $\varnothing_{i t}$ denote the slopes to be estimated and the residuals respectively. The equation indicates the relationship between $y_{i t}$ and time-invariant individual nuisance parameters $\rho_{i}$.

Meanwhile, before testing for stationarity, it is necessary to determine whether there is CSD in the panel data. For this purpose, the CSD test of Pesaran (2004) is employed, and the null hypothesis is that there is no CSD among the panel of countries in the study. The hypotheses for the test are explicitly stated as follows:

$$
\begin{gathered}
H_{0}: A_{i z}=A_{z i}=\operatorname{cor}\left(\mu_{i t}, \mu_{i t}\right)=0 \text { for } i \neq z \\
H_{1}: A_{i z}=A_{z i}=\operatorname{cor}\left(\mu_{i t}, \mu_{i t}\right) \neq 0 \text { for some } i \neq z
\end{gathered}
$$

\subsection{Panel cointegration test}

Over the years, panel cointegration techniques have come under intense scrutiny, especially concerning long-series panel data estimation (Pedroni, 1997). It has been found that traditional cointegration techniques are commonly more problematic in the application regarding period and less regarding data frequency (Perron, 1991). In addition, they have also been reported to often exhibit common-factor restrictions, in which case they fail to reject the null hypothesis of no cointegration, even when cointegration is strongly suggested by theory (Banerjee et al., 1998; Kremers et al., 1992). To investigate long-run relationships among the variables in the model, this study employs the panel cointegration technique of Westerlund (2007), which overcomes the deficiencies mentioned above by introducing four structural-based tests that do not suffer from any common-factor restrictions. Two of the tests are known as group mean statistics, and they assess the hypothesis that the panel is cointegrated as a whole. In contrast, the remaining two tests (panel statistics) assess the hypothesis that at least one unit in the panel is cointegrated. This technique is particularly suitable for this study because of its reliability even when there is CSD in the panel data (Persyn and Westerlund, 2008). The test rejects the null of no cointegration if the error-correction term in a panel error-correction model is significant; otherwise, the null is accepted (Westerlund, 2007). The technique's error-correction model is stated as follows:

$$
\Delta z_{i t}=\tau_{i}^{\prime} d_{t}+\omega_{i} z_{i t-1}+\delta_{i}^{\prime} x_{i t-1}+\sum_{j=1}^{p i} \omega_{i j} \Delta z_{i t-j}+\sum_{j=0}^{p i} \vartheta_{i j} \Delta x_{i t-j}+\epsilon_{i t}
$$

where $\omega_{i}$ is the error-correction parameter, measuring the speed at which the system is restored to equilibrium after an unexpected deviation from the path to long-run equilibrium. Also, $d_{t}=(1, t)^{\prime}$ accommodates the deterministic components with $\tau_{i}=\left(\tau_{1 i}, \tau_{2 i}\right)$ the vector of parameters.

\subsection{Augmented mean group estimator}

As mentioned earlier, it is imperative to account for CSD in error terms when investigating panel data. Failure to control for CSD could result in bias and misleading estimates (Pesaran, 2006; Turkay, 2017), and in studies on our subject, it could lead to wrong policy recommendations regarding the future of tourism. In light of this, equation (2) is re-specified as follows:

$$
\ln T D_{i t}=\beta_{0}+\beta_{1} \ln G D P_{i t}+\beta_{2} \ln E R_{i t}+\theta_{1} \ln E S G_{i t}+\theta_{2} \ln T O P_{i t}+\theta_{3} \ln / N F_{i t}+\rho_{i}+\tau_{i} f_{t}+\epsilon_{i t}
$$


In equation (7), the error term now encompasses country-specific time-invariant fixed effects $\left(\rho_{i}\right)$, white noise $\left(\epsilon_{i t}\right)$, and, very importantly, unobserved common factor $\left(f_{t}\right)$, with factor loadings $\left(\tau_{i}\right)$, which controls for time-invariant heterogeneity and CSD.

The error term in equation (7) is so broadened to overcome the problems as mentioned above arising from the likely presence of CSD in the panel. To estimate the model, this study employs the augmented mean group (AMG) estimator (Eberhardt and Teal, 2010), which is robust in the presence of CSD and is capable of giving the same level of quality and efficient estimates just as the common correlated effects mean group (CCEMG) estimator (Bond and Eberhardt, 2013; Eberhardt and Bond, 2009). This technique controls for CSD in panel data by employing "common dynamic effect", which is obtained from the time dummy coefficients of a pooled OLS regression in the first difference. Subsequently, the resulting common dynamic process is included as an additional regressor for each group-specific model.

\subsection{Dumitrescu-Hurlin panel causality test}

The final stage of our econometric process involves the testing of causal relationships between the variables in the model. Engle and Granger (1987) provides the basis for testing for causality among the variables by arguing that evidence of long-run relationship among a set of variables points to the existence of at least one-way causality between them. For the present study, the test for causality between international tourism demand and the explanatory variables as well as between all the destination factors in the model is important because it can provide information that would aid policymakers in their efforts to formulate effective policies aimed at improving the future marketing strategies of international demand for tourism in the V4, especially as a way of driving tourism recovery in the post-pandemic era. This is because it increases our understanding of how all the variables in the model relate with and have causal effect on one another. To this end, we apply the extended version of the Granger causality test, which is the Dumitrescu and Hurlin (2012) in order to explore the direction of causality between all the variables in the model. The $D-H$ panel causality test is more sophisticated than the traditional Granger causality tests, as it is enabled to account for the issues of heterogeneity and cross-sectional dependence in panel data. The null hypothesis assesses the non-homogeneous causality of one variable to another.

\subsection{Framework of methodology}

As adumbrated in Sections 3.2-3.5, this present study employs cutting-edge econometric procedures to achieve the stated objective. First off, the panel data is verified regarding the presence or otherwise of CSD through the use of cross-sectional dependence test of Pesaran (2004). This is followed by a conduct of investigation into the unit root properties of the data. To achieve this, the cross-sectionally augmented IPS (CIPS) unit root test of Pesaran (2007) is employed. After verifying the order of integration of the variables, we move ahead to test if the variables have long-run association, provided that all the variables are integrated of order 1 . The long-run relationship among the variables is tested by means of Westerlund (2007) test for cointegration. After confirming cointegration, the long-run elasticity among the variables is estimated with the augmented mean group (AMG) estimator (Eberhardt and Teal, 2010), and to test the robustness of the estimates, we also employ the common correlated effects mean group (CCEMG) estimator (Bond and Eberhardt, 2013; Eberhardt and Bond, 2009). Finally, in order to understand how the variables in the model interact with each other, with the aim of fostering efficient policy formulation for the future of tourism in the V4, the Granger causality relations between the variables are determined by employing the Dumitrescu-Hurlin $(D-H)$ panel causality test.

\section{Results and discussion}

\subsection{Descriptive statistics}

Table 2 reports the summary of descriptive statistics of the variables in the model. Over the 25-year study period, the $\mathrm{V} 4$ recorded an average of about 8.1 million international tourist arrivals, as well as 
Table 2 Descriptive statistics of variables

\begin{tabular}{lcccr} 
Variable & Mean & Std. deviation & Minimum & Maximum \\
\hline Tourist arrivals & $8,059,095$ & $5,966,331$ & 814,000 & $19,622,000$ \\
Tourism receipts & $5,740,000,000$ & $3,530,000,000$ & $441,000,000$ & $15,748,000,000$ \\
ESG risk rating & 28.908 & 6.839 & 15.077 & 49.715 \\
World GDP per capita & 9082.701 & 1041.645 & 7402.563 & 100 \\
Real effective exchange rate & 86.048 & 15.28 & 49.509 & 1007.02 \\
Trade openness & 119.189 & 37.711 & 43.722 & 111.828 \\
Infrastructure & $4,223,689$ & $5,428,101$ & 7,925 & 188.107 \\
& & & $31,226,848$ & 100 \\
& & & 100
\end{tabular}

about US $\$ 5.7$ billion international tourist receipts. The highest arrivals and receipts from international tourism of 19.6 million and US $\$ 15.7$ billion respectively, were received by Poland in 2018, while Slovakia had the lowest arrivals and receipts from international tourism at 814,000 in 1997 and US\$441 million in 2000 respectively. On average, the V4 received the countries' ESG rating of 28.9, which is quite encouraging, as it portrays the countries as being relatively low-risk regarding ESG factors. The best rating of 15.077 was received by the Czech Republic for 2018, while Hungary recorded the worst rating of 49.715 for 1995 . The mean World GDP per capita stands at US\$9082.70, while the World income per capita peaked in 2019 at US\$11057.02. It is noteworthy that World income per head has continued to rise steadily from US $\$ 7402.56$ in 1995 to the 2019 figure.

\subsection{Cross-sectional dependence and unit root tests}

The need to investigate the presence or otherwise of unobserved components and common shocks in models, which leads to the issue of CSD in error term cannot be overemphasised, as ignoring this might lead to misleading estimates (Pesaran, 2004; Turkay, 2017), and consequently, wrong policy recommendations for tourism future. To underscore its importance, De Hoyos and Sarafidis (2006) and Turkay (2017) assert that given the current era of globalisation and intereconomy interactions, CSD is considered a basic rule, rather than an expectation, between crosssectional units. Against this background, the CSD test of Pesaran (2004) is carried out on all the variables in the model. As reported in Table 3, the null hypothesis that there is cross-sectional independence in the series is rejected for all the variables at a $1 \%$ level of significance. This affirms the presence of CSD in all the series.

One important implication of the presence of CSD in panel data is that it can make the results of the first-generation unit root tests unreliable (Wagner, 2008). Thus, to prevent misleading test results, this study employs both first- and second-generation unit root tests. Specifically, in addition to firstgeneration tests of Levin et al. (2002) (LLC) and Im et al. (2003) (IPS), a second-generation test, known as cross-sectionally augmented IPS (CIPS) test of Pesaran (2007), which accounts for CSD in panel data, is also employed. As reported in Tables 4 and 5, findings from all the tests indicate

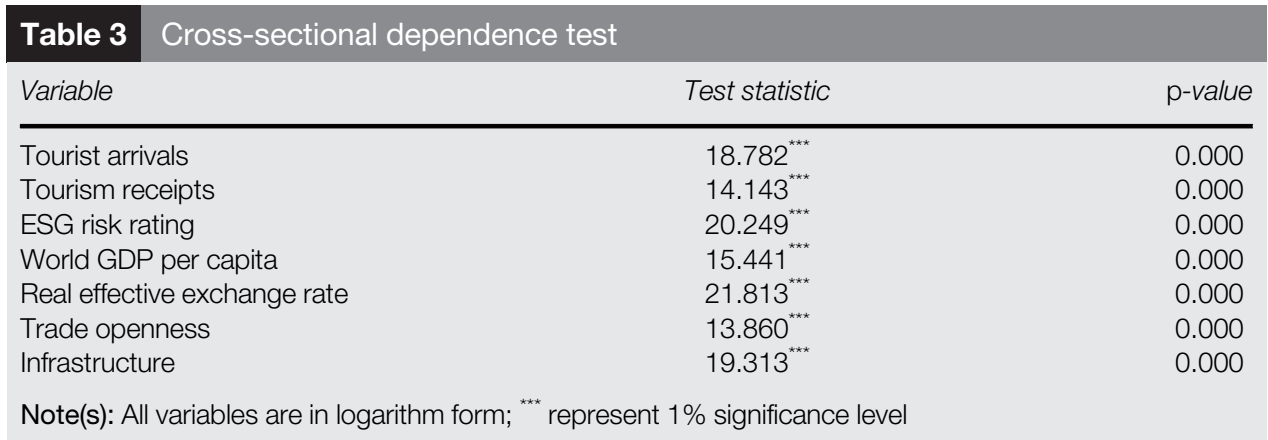

PAGE $10 \mid$ JOURNAL OF TOURISM FUTURES $\mid$ VOL. ... NO. ... 
Table 4 First-generation unit root tests

\begin{tabular}{|c|c|c|c|c|c|}
\hline \multirow[b]{2}{*}{ Variable } & \multicolumn{2}{|c|}{ LLC } & \multicolumn{2}{|c|}{ IPS } & \multirow[t]{2}{*}{ Decision } \\
\hline & Level & 1st difference & Level & 1st difference & \\
\hline Tourist arrivals & -0.339 & $-3.258^{\star \star \star *}$ & 1.304 & $-4.107^{\star \star \star *}$ & $\mathrm{I}(1)$ \\
\hline Tourism receipts & 0.639 & $-3.717^{\star \star \star}$ & 2.008 & $-2.843^{\star \star \star}$ & $\mathrm{I}(1)$ \\
\hline ESG risk rating & -0.319 & $-3.483^{\star \star \star}$ & 0.789 & $-5.631^{\star \star \star}$ & $\mathrm{I}(1)$ \\
\hline World GDP per capita & -1.089 & $-6.909^{\star * \star}$ & 1.885 & $-5.634^{\star \star \star}$ & $\mathrm{I}(1)$ \\
\hline Real eff. exchange rate & -2.436 & $-4.089^{* \star * *}$ & -1.296 & $-3.318^{\star \star * x}$ & $\mathrm{l}(1)$ \\
\hline Trade openness & -2.974 & $-6.118^{\star \star \star}$ & -0.819 & $-5.238^{\star \star \star \star}$ & $\mathrm{I}(1)$ \\
\hline Infrastructure & 0.602 & $-5.717^{\star \star \star}$ & 1.673 & $-4.883^{* \star *}$ & $\mathrm{I}(1)$ \\
\hline
\end{tabular}

\section{Table 5 CIPS panel unit root test}

\begin{tabular}{lccccc} 
& \multicolumn{2}{c}{ Level } & \multicolumn{2}{c}{ First difference } \\
Variable & Test statistic & p-value & Test statistic & p-value & Decision \\
\hline Tourist arrivals & 2.418 & 0.271 & $-6.518^{* \star *}$ & 0.000 & $1(1)$ \\
Tourism receipts & -0.521 & 0.174 & $-7.227^{* \star *}$ & 0.000 & $1(1)$ \\
ESG risk rating & -2.557 & 0.114 & $-4.111^{* *}$ & 0.014 & $1(1)$ \\
World GDP per capita & 3.541 & 0.316 & $-2.106^{* \star *}$ & 0.000 & $1(1)$ \\
Real effective exchange rate & -1.293 & 0.225 & $-6.004^{* *}$ & 0.000 & $1(1)$ \\
Trade openness & 2.130 & 0.212 & $-3.173^{* \star *}$ & 0.000 & $1(1)$ \\
Infrastructure & -1.059 & 0.164 & $-2.291^{* *}$ & 0.029 & $1(1)$
\end{tabular}

Note(s): All variables are in logarithm form; ${ }^{* * *}$ and ${ }^{* \star}$ are significance levels at $1 \%$ and $5 \%$, respectively

that all the variables are stationary only at first difference. Thus, there is a need to investigate the presence of cointegration among the variables in the model. Moreover, the absence of any I(2) variable in the model indicates that the AMG and CCEMG estimation techniques are appropriate for the study.

\subsection{Panel cointegration test}

As a way of controlling for cross-sectional dependence, which is already confirmed to be present in the data, this study employs the error-correction-based test for cointegration, developed by Westerlund (2007). As reported in Table 6, the null hypothesis that the variables are not cointegrated is rejected by the group mean statistics $\left(G_{t}\right.$ and $\left.G_{a}\right)$ in the two models with international tourist arrivals and international tourism receipts as the dependent variables. In a similar vein, the panel statistics $\left(P_{t}\right.$ and $\left.P_{a}\right)$ in both models also reject the null hypothesis of no cointegration among the variables. This result confirms the presence of a long-run association among the variables in the model. The coefficients of parameters in the model can now be estimated using an AMG estimator.

\section{Table 6 Westerlund panel cointegration test}

\begin{tabular}{|c|c|c|c|c|}
\hline \multirow[b]{2}{*}{ Test } & \multicolumn{2}{|c|}{$D V=$ international tourist arrivals } & \multicolumn{2}{|c|}{$D V=$ international tourism receipts } \\
\hline & Value & p-value & Value & p-value \\
\hline$G_{t}$ & $-7.337^{\star \star \star \star}$ & 0.000 & $-5.417^{\star \star \star}$ & 0.000 \\
\hline$G_{a}$ & $-4.219^{* *}$ & 0.018 & $-11.964^{\star \star \star *}$ & 0.009 \\
\hline$P_{t}$ & $-16.532^{\star \star \star x}$ & 0.000 & $-6.211^{\star \star \star}$ & 0.000 \\
\hline$P_{a}$ & $-6.005^{* \star *}$ & 0.004 & $-5.935^{\star \star}$ & 0.026 \\
\hline
\end{tabular}

Note(s): DV = Dependent Variable; ${ }^{\star \star \star}$ and ${ }^{\star \star}$ are significance levels at $1 \%$ and $5 \%$, respectively 


\subsection{Panel regression results}

The long-run elasticity estimates of the regressors in the AMG model are presented in Table 7. There are two different regressions for the model. The first regression has the total number of international tourist arrivals as the proxy for the dependent variable. In contrast, in the second regression, the total amount of international tourism receipts is the proxy for the dependent variable. The first regression shows that the countries' ESG risk rating is negative and statistically significant at 5\%. This result indicates that an increase in the rating of the risks regarding ESG factors in the V4 is associated with a decrease in the number of international tourist arrivals to the area. In other words, the higher the risk regarding the ESG factors, the lower the demand for international tourism. Specifically, the coefficient of the countries' ESG risk rating $(-0.00452)$ reveals that by holding other factors constant, a 1\% decrease in ESG risk rating would lead to an increase in the number of international tourist arrivals by about $0.005 \%$, and vice-versa. This result reveals that intending tourists to the V4 somehow put the risks associated with ESG factors into consideration when deciding to embark on tourism to the area. This is in line with previous positions of researchers on the subject.

For example, Antonakakis et al. (2016), Tang and Tan (2016) and Usman et al. (2020) claim that environmental quality and robust democracy enhances international tourism demand. On social factors, the result corroborates the finding from Kim et al. (2020) that social trust exerts a significant impact on the development of tourism across countries, as well as from Ghalia et al. (2019) that a lower risk of conflict in a country is associated with increased inflow of tourists. The result is also supported by the claim in Tang and Tan (2016) that international tourists are sensitive to the issues of crime, health and security when deciding on their destination for tourism. On governance issues, the finding of this study is in agreement with a plethora of results from extant studies in affirmation of the positive impact of good governance on tourism demand (Detotto et al., 2021; Saha and Yap, 2014; Yap and Saha, 2013). Overall, this result indicates that perception regarding the risks associated with ESG factors, as reflected by the countries' ESG risk rating, matters to potential tourists to the V4, more so regarding their future tourism plans. The countries' ESG risk rating coefficient in the second regression with the number of receipts from international tourism as the dependent variable is equally negative and significant at $5 \%$, which corroborates the result of the first regression. The coefficient of -0.01027 reveals that if other factors are held constant, a $1 \%$ decrease in the countries' ESG risk rating will increase the number of international tourism receipts by about $0.01 \%$. It is, however, noteworthy that considering the magnitude of the coefficients of ESG risk rating in both regressions, especially relative to those of other variables in the model, ESG risk rating seems to be less important than other determinants of tourism demand in the model, as it yields the lowest coefficients among all the variables in the model.

The coefficients of world GDP per capita in both regressions is positive and significant at $1 \%$. With the coefficients of 1.0462 and 1.0052, the variable is shown to exert a positive elastic impact on international tourism demand in the V4. Specifically, the results imply that if we hold other factors constant, a $1 \%$ increase in income levels would enhance international tourism arrivals and

Table 7 Results of AMG estimation

\begin{tabular}{|c|c|c|c|c|}
\hline \multirow[b]{2}{*}{ Variable } & \multicolumn{2}{|c|}{$\begin{array}{c}D V=\text { international tourist } \\
\text { arrivals }\end{array}$} & \multicolumn{2}{|c|}{$\begin{array}{c}D V=\text { international tourism } \\
\text { receipts }\end{array}$} \\
\hline & Coefficient & p-value & Coefficient & p-value \\
\hline ESG risk rating & $-0.00452^{* *}$ & 0.027 & $-0.010274^{\star \star}$ & 0.011 \\
\hline World GDP per capita & $1.0462^{\star \star \star}$ & 0.000 & $1.00524^{\star \star \star}$ & 0.000 \\
\hline Real effective exchange rate & $-0.1422^{\star \star \star}$ & 0.000 & $-0.13855^{\star \star}$ & 0.027 \\
\hline Trade openness & $0.01508^{*}$ & 0.053 & $0.02251^{*}$ & 0.061 \\
\hline Infrastructure & $0.0355^{\star \star \star}$ & 0.000 & $0.00772^{\star \star \star}$ & 0.000 \\
\hline
\end{tabular}

Note(s): DV = Dependent variable; All variables are in logarithmic forms; ${ }^{* * *}$, ${ }^{* *}$ and ${ }^{*}$ are significance levels at $1 \%, 5 \%$ and $10 \%$, respectively 
international tourism receipts by about $1.05 \%$ and $1.01 \%$, respectively, and vice-versa. The magnitudes of the coefficients of the variable, compared to others in the model, reveal that income appears to be the most influential factor for international tourism demand among all the variables in the model. Another implication of the coefficients of the income variable being more significant than unity in both regressions (1.0462 and 1.0052) is that it suggests that potential tourists around the world perceive tourism to the V4 as a luxury, thus making the prevailing economic conditions in the originating countries a key determinant of tourism development in the V4. This result is in line with the finding of extant studies that the demand for international tourism is susceptible to income levels in originating countries (Habibi, 2017; Surugiu et al., 2011; Tang, 2018; Tang and Tan, 2016; Usman et al. , 2020). Thus, plans targeted at the future of tourism would benefit from global growth forecasts.

The relative price of tourism is represented by the real effective exchange rate (REER), which measures the value of a currency vis-à-vis a basket of other major currencies, thus indicating that a higher REER results in exports and/or international tourism becoming more expensive. The coefficients of REER is found to be significant and negative in both regressions. The coefficient values of -0.1422 and -0.1386 in the two regressions reveal that other factors remaining constant, a $1 \%$ increase in the real effective exchange rate (and consequently, in the relative price of tourism) would result in $0.142 \%$ and $0.139 \%$ decline in the number of tourist arrivals and amount of tourism receipts respectively. This finding calls for the need for the $\mathrm{V} 4$ always to maintain a relatively stable exchange rate, as suggested by De Vita (2014). This result supports De Vita (2014) which found that the exchange rate negatively influences the demand for tourism. It is also in line with the consumer behaviour theory and past studies that affirm that demand for tourism exudes a negative response to the price of tourism (Habibi, 2017; Surugiu et al., 2011; Tang and Tan, 2016; Usman et al., 2020).

The coefficient of trade openness is found to be positive and weakly significant at 10\% in the two regressions. This indicates that the expansion of international trade in the $\mathrm{V} 4$ is associated with an increase in international tourism demand. The coefficients of 0.01508 and 0.02251 imply that if other factors are held constant, a $1 \%$ increase in international trade will enhance the number of international tourist arrivals and international tourism receipts by about $0.015 \%$ and $0.023 \%$, respectively. This result is in line with a priori expectation because business travel is an important requisite to initiate and carry on international trade (Santana-Gallego et al., 2011), and considering the fact extant studies have disaggregated tourist flows into different motives for a visit, one of which is business (Song and Witt, 2003; Turner and Witt, 2001). Empirically, several studies have identified international trade as an important generator of international tourism flows (Detotto et al., 2021; Leitão, 2010; Surugiu et al., 2011). Nonetheless, finding by Habibi and Khalid (2009) show that indicate that changes in bilateral trade between Malaysia and Indonesia/Japan/Philippines have no impact on tourist inflows to the country.

Lastly, the coefficient of infrastructure, denoted by the number of passengers carried by air transport, is positive and significant at the $1 \%$ level in the two regressions. This shows that improvement in the level of infrastructure in the $\mathrm{V} 4$ attracts international tourists. The coefficients of the variable, which stand at 0.0355 and 0.0077 , imply that if we hold other factors constant, a $1 \%$ improvement in infrastructure will result in about $0.036 \%$ and $0.008 \%$ increase in the number of international tourist arrivals and amount of international tourism receipts respectively. Intuitively, there is an expectation of a minimum level of infrastructure from most potential tourists, the absence of which they consider might result in them not having a worthwhile visit. Thus, these results bespeak the need to invest in critical infrastructure in order to embellish the future of tourism in the V4. This is in line with previous findings that infrastructure plays a crucial role in attracting tourists (De Vita, 2014; Khadaroo and Seetanah, 2008).

\subsection{Robustness check}

The results are validated by robustness checks that involve estimating the model through common correlated effects mean group (CCEMG) estimator developed by Pesaran (2006). 
Just as is the case with the AMG estimator, the CCEMG estimator is equipped to account for heterogeneous slopes and CSD in panel data. In addition, it is robust to issues of structural breaks and unobserved common factors in data (Pesaran, 2006). The estimator arrives at the estimates by adding the averages of all the countries for both the dependent variable and the regressors. These are then included in the model as additional regressors (Pesaran, 2006). The results of the CCEMG estimations are presented in Table 8 for the two regressions with the number of international tourist arrivals and the number of international tourism receipts as the dependent variables. A close look at the results of the two regressions shows that the estimates are principally the same as those of the AMG estimator in terms of significance and signs. Thus, the robustness tests confirm that in line with the AMG results, countries' ESG risk-rating influences international tourism demand in the $\mathrm{V} 4$ and that income remains the most important determinant of tourism demand in the area. This indicates that the estimates are robust to alternative methods of estimation.

\subsection{Results of Dumitrescu-Hurlin panel causality test}

As a way of understanding the causal relationship among the variables in the model, a panel causality test proposed by Dumitrescu and Hurlin (2012) is conducted. This causality test is renowned for its accommodation of the problem of cross-sectional dependence, which has already been confirmed to be present in our panel data. The outcomes of the test which are presented in Table 9 show that international tourism demand (TD) has a bidirectional causal relationship with ESG risk rating, relative prices (REER) and trade openness (TOP). These results are line with extant studies by Solarin (2014) and Kulendran and Wilson (2000). This indicates that there is a tendency for a feedback effect between TD and each of the three destination factors. The reverse causality between TD and ESG risk indicates that improvement in environmental, social and governance factors could engender productivity and efficiency in the tourism industry, thereby increasing international tourism receipts and future international tourism demand. Moreover, in order to sustain this trajectory into the future, the governments endeavour to rejig their policies, processes and structures in order to improve environmental sustainability, human rights protection and free market, as evidenced by Göymen (2000). The reverse causality of price of tourism and trade openness with tourism implies that the influx of tourists occasioned by improvement of these factors in turn improve future international trade, which provides the basis for business tourism, while also encouraging a real effective exchange rate that is conducive for tourism. Furthermore, a unidirectional causality is established from world income to tourism demand, from trade openness to ESG and REER, and from tourism demand to infrastructure. These results confirm the findings of Shafiullah et al. (2018) for Australia and also bespeak the important role that openness to international trade plays in driving international tourism to the $\mathrm{V} 4$, and the need for the countries to formulate sound policies around it as a way of brightening the future of international tourism in the area.

Table 8 Results of CCEMG estimation

\begin{tabular}{|c|c|c|c|c|}
\hline \multirow[b]{2}{*}{ Variable } & \multicolumn{2}{|c|}{$\begin{array}{c}D V=\text { international tourist } \\
\text { arrivals }\end{array}$} & \multicolumn{2}{|c|}{$\begin{array}{c}D V=\text { international tourism } \\
\text { receipts }\end{array}$} \\
\hline & Coefficient & $\mathrm{p}$-value & Coefficient & $\mathrm{p}$-value \\
\hline ESG risk rating & $-0.0218^{\star \star \star}$ & 0.000 & $-0.00849^{\star *}$ & 0.015 \\
\hline World GDP per capita & $1.1172^{\star \star * *}$ & 0.000 & $1.07516^{* \star *}$ & 0.000 \\
\hline Real effective exchange rate & $-0.2017^{\star \star x+x}$ & 0.000 & $-0.51704^{\star \star}$ & 0.010 \\
\hline Trade openness & $0.03470^{*}$ & 0.057 & $0.08217^{* \star}$ & 0.039 \\
\hline Infrastructure & $0.0709^{* \star \star}$ & 0.000 & $0.00997^{\star \star \star *}$ & 0.000 \\
\hline
\end{tabular}

PAGE 14 |JOURNAL OF TOURISM FUTURES | VOL. m. NO. m. 
Table 9 Results of Dumitrescu-Hurlin panel causality test

\begin{tabular}{lcccrrr} 
Variable & TD & ESG & GDP & REER & TOP & INFR \\
\hline TD & & $0.047^{* *}(2.319)$ & $0.634(1.551)$ & $0.006^{* *}(2.218)$ & $0.918^{* *}(2.371)$ & $1.087^{* * *}(9.216)$ \\
ESG & $0.251^{* * *}(3.764)$ & & $0.331(0.917)$ & $1.117(0.937)$ & $0.337(1.092)$ & $0.191(1.667)$ \\
GDP & $0.917^{* * *}(11.526)$ & $0.371(1.534)$ & & $0.366(1.641)$ & $0.313(1.637)$ & $0.214(0.716)$ \\
REER & $0.103^{*}(1.924)$ & $2.341(1.138)$ & $0.617(0.627)$ & & $1.071(0.994)$ & $0.018(0.406)$ \\
TOP & $0.522^{* * *}(2.907)$ & $0.475^{*}(1.933)$ & $0.657(1.682)$ & $0.651^{*}(1.957)$ & & $1.701(1.538)$ \\
INFR & $0.493(0.083)$ & $0.807(1.433)$ & $0.911(1.073)$ & $1.057(1.279)$ & $0.007(1.071)$
\end{tabular}

Note(s): All variables are in logarithmic forms; ${ }^{* * *},{ }^{* *}$ and ${ }^{*}$ are significance levels at $1 \%, 5 \%$ and $10 \%$, respectively

\section{Conclusion}

This study investigated the influence of countries' ESG risk rating on international tourism demand in the context of the Visegrád countries, comprising the Czech Republic, Hungary, Poland and Slovakia. In order to account for the likely presence of cross-sectional dependence in the data, the augmented mean group (AMG) and common correlated effect mean group (CCEMG) estimators were utilised to estimate the model. Furthermore, in order explore how the variables in the model interact, we employed the Dumitrescu-Hurlin panel causality test. Findings from the study indicate that besides economic factors such as income, relative prices, trade openness and infrastructure, perception of international tourists on the level of risk pertaining to environmental, social and governance factors are additional fundamental considerations in determining the level of inbound international tourism demand in the V4. Specifically, we note that international tourists are sensitive to the ESG risk rating of the V4, such that higher ESG risks in the V4 are associated with reduced international tourist arrivals/tourism receipts. The study also established income in the tourists' originating countries as the most crucial determinant of international tourism demand in the V4. In particular, tourism to the V4 is deemed a luxury, going by the positive, elastic income effect. The only limitation of the study is the limited annual number of observations regarding the country risk ratings. Future research will include comparisons of other regions and countries and the inclusion of different variables.

The findings from this study have a number of policy implications for the future of tourism in the V4. First off, there is need for the V4 to further improve their ESG risk rating by working towards further mitigating risks associated with environmental, social and governance factors. At 28.91/ 100 , the mean risk rating for the four countries over the 25 years appears to be relatively decent, but then, considering the ongoing coronavirus COVID-19-induced travel restrictions, there is a need for the V4 to take proactive steps towards attracting international tourists by way of reducing or eliminating any negative perceptions about tourism in the area, ahead of the postpandemic era. Furthermore, following the result's implication that tourism to the V4 is considered a luxury, there is a need for the monetary authorities in the area to foster their tourism competitiveness by ensuring exchange rate stability. Exchange rate volatility could engender uncertainty and sudden spikes in the cost of living, and consequently, in the relative price of tourism in the area. Besides, policymakers should orient policies towards expanding international trade and improving infrastructural facilities with the deliberate objective of increasing international tourism demand. The panel causality test results have indicated international trade as being central, not only to international tourism demand, but also to other destination factors in the mix. This suggests that trade is very important to the future of international tourism in the $\mathrm{V} 4$, and emphasis should be put on policies to improve it in the area. Lastly, the overview of ESG risk rating in relation to its assessment of tourism futures suggests the need for a generally agreed-upon underlying principle in the computation of ESG ratings, while also advocating a blend of both qualitative and quantitative methodology, as a way of enhancing the predictive capabilities of ESG risk ratings, which could in turn improve the quality of future tourism decisions. 


\section{References}

Abedtalas, M. and Toprak, L. (2015), "The determinants of tourism demand in Turkey", Journal of Economics and Behavioral Studies, Vol. 7 No. 4, pp. 90-105.

Aguiló, E., Alegre, J. and Sard, M. (2005), "The persistence of the sun and sand tourism model", Tourism Management, Vol. 26 No. 2, pp. 219-231.

Akadiri, S.S., Akadiri, A.C. and Alola, U.V. (2017), "Is there growth impact of tourism? Evidence from selected small island states", Current Issues in Tourism, Vol. 22 No. 12, pp. 1480-1498.

Antonakakis, N., Dragouni, M., Eeckels, B. and Filis, G. (2016), "Tourism and economic growth: does democracy matter?", Annals of Tourism Research, Vol. 61, pp. 258-264.

Araña, J.E. and León, C.J. (2008), "The impact of terrorism on tourism demand", Annals of Tourism Research, Vol. 35 No. 2, pp. 299-315.

Balcilar, M., van Eyden, R., Inglesi-Lotz, R. and Gupta, R. (2014), "Time-varying linkages between tourism receipts and economic growth in South Africa", Applied Economics, Vol. 46 No. 36, pp. 4381-4398.

Balli, E., Sigeze, C., Manga, M., Birdir, S. and Birdir, K. (2019), "The relationship between tourism, CO2 emissions and economic growth: a case of Mediterranean countries", Asia Pacific Journal of Tourism Research, Vol. 24, pp. 219-232.

Ballia, F., Shahzad, S.J.H. and Salah Uddin, G. (2018), "A tale of two shocks: what do we learn from the impacts of economic policy uncertainties on tourism?", Tourism Management, Vol. 68, pp. 470-475.

Banerjee, A., Dolado, J. and Mester, R. (1998), "Error-correction mechanism tests for cointegration in a single-equation framework", Journal of Time Series Analysis, Vol. 19 No. 3, pp. 267-283.

Banerjee, A., Cockerell, L. and Russell, B. (2001), "An I(2) analysis of inflation and the mark up", Journal of Applied Econometrics, Vol. 16 No. 3, pp. 221-240.

Berrittella, M., Bigano, A., Roson, R. and Tol, R.S.J. (2006), "A general equilibrium analysis of climate change impacts on tourism", Tourism Management, Vol. 27 No. 5, pp. 913-924.

Billio, M., Costola, M., Hristova, I., Latino, C. and Pelizzon, L. (2020), "Inside the ESG ratings: (dis)agreement and performance", Corporate Social Responsibility and Environmental Management, Vol. 28, pp. 1426-1445.

Bond, S.R. and Eberhardt, M. (2013), "Accounting for unobserved heterogeneity in panel time series models", Discussing Paper, Nottingham.

Cothran, D.A. and Cothran, C.C. (1998), "Promise or political risk for Mexican tourism", Annals of Tourism Research, Vol. 25 No. 2, pp. 477-497.

CountryRisk.io (2020), available at: https://www.countryrisk.io/methodology/esg-risk-score/current-versionjuly-2020 (accessed 15 January 2021).

Crifo, P., Diaye, M. and Oueghlissi, R. (2017), "The effect of countries' ESG ratings on their sovereign borrowing costs", The Quarterly Review of Economics and Finance, Vol. 66, pp. 13-20.

Czech Tourism (2017), Discover Central Europe: 2016 Facts \& Figures, Czech Tourism, Prague.

De Hoyos, R.E. and Sarafidis, V. (2006), "Testing for cross-sectional dependence in panel-data models", The Stata Journal, Vol. 6 No. 4, pp. 482-496.

De Vita, G. (2014), "The long-run impact of exchange rate regimes on international tourism flows", Tourism Management, Vol. 45, pp. 226-233.

Demir, E. and Gozgor, G. (2018), "Does economic policy uncertainty affect tourism?", Annals of Tourism Research, Vol. 69, pp. 15-17.

Detotto, C., Giannoni, S. and Goavec, C. (2021), "Does good governance attract tourists?", Tourism Management, Vol. 82, pp. 1-9.

Dogru, T., Sirakaya-Turk, E. and Crouch, G. I. (2017), "Remodelling international tourism demand: old theory and new evidence", Tourism Management, Vol. 60, pp. 47-55.

Dorfleitner, G., Halbritter, G. and Nguyen, M. (2015), "Measuring the level and risk of corporate responsibility - an empirical comparison of different ESG rating approaches", Journal of Asset Management, Vol. 16 No. 7 , pp. 450-466. 
Du, D., Lew, A.A. and Ng, P.T. (2016), "Tourism and economic growth”, Journal of Travel Research, Vol. 55, pp. 454-464.

Dumitrescu, E.I. and Hurlin, C. (2012), "Testing for Granger non-causality in heterogeneous panels", Economic Modelling, Vol. 29 No. 4, pp. 1450-1460.

Eberhardt, M. (2012), "Estimating panel time-series models with heterogeneous slopes", The Stata Journal, Vol. 12 No. 1, pp. 61-71.

Eberhardt, M. and Bond, S. (2009), "Cross-section dependence in non-stationary panel models: a novel estimator", Munich Personal RePEc Archive Working Paper No. 17870.

Eberhardt, M. and Teal, F. (2010), "Productivity analysis in global manufacturing production", Economics Series Working Paper No. 515, Department of Economics, University of Oxford.

Edgell, D.L.S., DelMastro Allen, M., Smitch, G. and Swanson, J.R. (2013), Tourism Policy and Planning: Yesterday, Today, and Tomorrow, 2nd ed., Routledge, London.

Ejemeyovwi, J.O., Osabuohien, E.S. and Osabohien, R. (2018), "ICT investments, human capital development and institutions in ECOWAS", International Journal of Economic and Business Research, Vol. 15 No. 4, pp. 463-474.

Engle, R.F. and Granger, C.W.J. (1987), "Co-integration and error correction: representation, estimation, and testing”, Econometrica, Vol. 55 No. 2, pp. 251-276.

Eugenio-Martin, J.L. (2003), "Modelling determinants of tourism demand as a five-stage process: a discrete choice methodological approach", Tourism and Hospitality Research, Vol. 4 No. 4, pp. 340-353.

Friedman, M. (1949), "The Marshallian demand curve”, Journal of Political Economy, Vol. 57 No. 6, pp. 463-495.

Ghalia, T., Fidrmuc, J., Samargandi, N. and Sohag, K. (2019), "Institutional quality, political risk and tourism", Tourism Management Perspective, Vol. 32, pp. 1-10.

Gössling, S. and Hall, C.M. (2006), "Uncertainties in predicting tourist flows under scenarios of climate change", Climatic Change, Vol. 79, pp. 163-173.

Göymen, K. (2000), "Tourism and governance in Turkey", Annals of Tourism Research, Vol. 27 No. 4, pp. $1025-1048$.

Habibi, F. (2017), "The determinants of inbound tourism to Malaysia: a panel data analysis", Current Issues in Tourism, Vol. 20 No. 9, pp. 909-930.

Habibi, F. and Khalid, A.R. (2009), "A bound test approach to cointegration of tourism demand to Malaysia", American Journal of Applied Science, Vol. 6 No. 7, pp. 1410-1417.

Hall, C.M. and O'Sullivan, V. (1996), "Tourism, political instability and violence”, in Pizam, A. and Mansfeld, A. (Eds), Tourism, Crime and International Security Issues, Wiley, New York, NY, pp. 105-121.

Hamilton, J.M., Maddison, D.J. and Tol, R.S.J. (2005), "Climate change and international tourism: a simulation study”, Global Environmental Change, Vol. 15 No. 3, pp. 253-266.

Hungarian Central Statistical Office (2018), "Main indicators of the Visegrád group countries", Prepared by the Hungarian Central Statistical Office in cooperation with statistical offices of Czech Republic, Poland and Slovakia.

Im, K.S., Pesaran, M.H. and Smith, Y. (2003), "Testing unit roots in heterogeneous panels", Journal of Econometrics, Vol. 115, pp. 53-74.

Jalil, A., Mahmood, T. and Idrees, M. (2013), "Tourism-growth nexus in Pakistan: evidence from ARDL bounds tests", Economic Modelling, Vol. 35, pp. 185-191.

Khadaroo, J. and Seetanah, B. (2008), "The role of transport infrastructure in international tourism development: a gravity model approach", Tourism Management, Vol. 29 No. 5, pp. 831-840.

Khalid, U., Okafor, L.E. and Aziz, N. (2019), "Armed conflict, military expenditure and international tourism", Tourism Economics, Vol. 26 No. 4, pp. 555-577.

Kim, Y.R., Saha, S., Vertinsky, I. and Park, C. (2018), "The impact of national institutional quality on international tourism inflows: a cross-country evidence", Tourism Analysis, Vol. 23, pp. 533-551.

Kim, Y., Yap, G. and Vertinsky, I. (2020), "Can 'too much' trust slow tourism development? An exploratory cross-country analysis", Current Issues in Tourism, Vol. 24 No. 13, pp. 1803-1808, doi: 10.1080/13683500. 2020.1754353. 
Kremers, J.M., Ericsson, N.R. and Dolado, J. (1992), "The power of cointegration tests", Oxford Bulletin of Economics and Statistics, Vol. 54, No. 3, pp. 325-348.

Kulendran, N. and Wilson, K. (2000), "Is there a relationship between international trade and international travel”, Applied Economics, Vol. 32 No. 8, pp. 1001-1009.

Lee, H.S., Sin Yee, L.E.E. and Har, W.M. (2020), "Roles of institutional quality on the relationship between tourism and economic development in Malaysia", Journal of Environmental Treatment Techniques, Vol. 8 No. 1 , pp. 119-124.

Leitão, N.C. (2010), "Does trade help to explain tourism demand? The case of Portugal", Theoretical and Applied Economics, Vol. 17 No. 3, pp. 63-74.

Levin, A., Lin, C.F. and Chu, C. (2002), "Unit root tests in panel data: asymptotic and finite-sample properties", Journal of Econometrics, Vol. 108, pp. 1-24.

Maddala, G.S. and Wu, S. (1999), "A Comparative study of unit root tests with panel data and a new simple test", Oxford Bulletin of Economics and Statistics, Vol. 61, pp. 631-652.

Martins, L.F., Gan, Y. and Ferreira-Lopes, A. (2017), "An empirical analysis of the influence of macroeconomic determinants on World tourism demand", Tourism Management, Vol. 61, pp. 248-260.

Morley, C.L. (1994), "The use of CPI for tourism prices in demand modelling", Tourism Management, Vol. 15 No. 5 , pp. 342-346

Morley, C., Rosselló, J. and Santana-Gallego, M. (2014), "Gravity models for tourism demand: theory and use", Annals of Tourism Research, Vol. 48, pp. 1-10.

Pagano, M.S., Sinclair, G. and Yang, T. (2018), "Understanding ESG ratings and ESG indexes”, in Boubaker, S., Cumming, D. and Nguyen, D.K. (Eds), Research Handbook of Finance and Sustainability, Edward Elgar. doi: 10.4337/9781786432636 (accessed 23 November 2021).

Pedroni, P. (1997), "Cross sectional dependence in cointegration tests of purchasing power parity in panels", Working Paper, Department of Economics, Indiana University.

Peng, B., Song, H., Crouch, G.I. and Witt, S.F. (2014), "A meta-analysis of international tourism demand elasticities", Journal of Travel Research, Vol. 54 No. 5, pp. 611-633, doi: 10.1177/0047287514528283.

Perron, P. (1991), "Test consistency with varying sampling”, Econometric Theory, Vol. 7 No. 3, pp. 341-368.

Persyn, D. and Westerlund, J. (2008), "Error-correction based cointegration tests for panel data", The Stata Journal, Vol. 8 No. 2, pp. 232-241.

Pesaran, M.H. (2004), "General diagnostic tests for cross-section dependence in panel", IZA Discussion Paper No. 1240.

Pesaran, M.H. (2006), "Estimation and inference in large heterogeneous panels with multifactor error structure", Econometrica, Vol. 74 No. 4, pp. 967-1012.

Pesaran, M.H. (2007), "A simple panel unit root test in the presence of cross-section dependence", Journal of Applied Econometrics, Vol. 22, pp. 265-312.

Pizam, A. and Mansfeld, Y. (2006), "Toward a theory of tourism security", Tourism, Security and Safety, Routledge, pp. 15-41.

Pratt, S. (2015), "The economic impact of tourism in SIDS", Annals of Tourism Research, Vol. 52, pp. $148-160$.

Rasekhi, S., Karimi, S. and Mohammadi, S. (2016), "Environmental impacts of tourism: a case study of selected developing and developed countries", The Journal of Tourism Planning and Development, Vol. 5 No. 16, pp. 71-94.

Ridderstaat, J., Oduber, M., Croes, R., Nijkamp, P. and Martens, P. (2014), "Impacts of seasonal patterns of climate on recurrent fluctuations in tourism demand: evidence from Aruba", Tourism Management, Vol. 41, pp. 245-256.

Roudi, S., Arasli, H. and Akadiri, S.S. (2018), "New insights into an old issue-examining the influence of tourism on economic growth: evidence from selected small island developing states", Current Issues in Tourism, Vol. 22 No. 11, pp. 1-21.

Sadorsky, P. (2013), "Do urbanisation and industrialisation affect energy intensity in developing countries?", Energy Economics, Vol. 37, pp. 52-59. 
Saha, S. and Yap, G. (2014), "The moderation effects of political instability and terrorism on tourism development: a cross-country panel analysis", Journal of Travel Research, Vol. 53 No. 4, pp. 509-521.

Santana-Gallego, M., Ledesma-Rodríguez, F. and Pérez-Rodríguez, J.V. (2011), "Tourism and trade in small island regions: the case of the Canary Islands", Tourism Economics, Vol. 17 No. 1, pp. 107-125.

Schiffman, L.G. and Kanuk, L.L. (1997), Consumer Behaviour, 6th ed., Singapura Publisher, Prentice Hall, New Jersey.

Seetanah, B., Durbarry, R. and Ragodoo, J.F. (2010), "Using the panel cointegration approach to analyse the determinants of tourism demand in South Africa", Tourism Economics, Vol. 16 No. 3, pp. 715-729.

Shafiullah, M., Okafor, L.E. and Khalid, U. (2018), "Determinants of international tourism demand: evidence from Australian states and territories", Tourism Economics, Vol. 25 No. 2, pp. 274-296.

Solarin, S.A. (2014), "Tourist arrivals and macroeconomic determinants of CO2 emissions in Malaysia", Anatolia, Vol. 25, pp. 228-241.

Song, H. and Witt, S.F. (2003), "Tourism forecasting: the general-to-specific approach", Journal of Travel Research, Vol. 42 No. 1, pp. 65-74.

Surugiu, C., Leitão, N.C. and Surugiu, M.R. (2011), "A panel data modelling of international tourism demand: evidences for Romania”, Economic Research-Ekonomska Istraživanja, Vol. 24 No. 1, pp. 134-145, doi: 10. 1080/1331677X.2011.11517450.

Takahashi, K. (2020), "Comparing the determinants of tourism demand in Singapore and French Polynesia: applying the tourism demand model to panel data analysis", Tourism Analysis, Vol. 25, pp. 175-181.

Tang, C.F. (2018), "The impacts of governance and institutions on inbound tourism demand: evidence from a dynamic panel data study", Asia Pacific Journal of Tourism Research, Vol. 23 No. 10, pp. 1000-1007, doi: 10.1080/10941665.2018.1513052.

Tang, C.F. and Abosedra, S. (2014), "Small sample evidence on the tourism-led growth hypothesis in Lebanon", Current Issues in Tourism, Vol. 17 No. 3, pp. 234-246.

Tang, C.F. and Lau, E. (2017), "Modelling the demand for inbound medical tourism: the case of Malaysia", International Journal of Tourism Research, Vol. 19 No. 5, pp. 584-593.

Tang, C.F. and Tan, E.C. (2015), "Does tourism effectively stimulate Malaysia's economic growth?", Tourism Management, Vol. 46, pp. 158-163.

Tang, C.F. and Tan, E.C. (2016), "The determinants of inbound tourism demand in Malaysia: another visit with non-stationary panel data approach", Anatolia, Vol. 27 No. 2, pp. 189-200.

Tavares, J.M. and Leitão, N.C. (2017), "The determinants of international tourism demand for Brazil", Tourism Economics, Vol. 23 No. 4, pp. 834-845.

Thompson, A. (2011), "Terrorism and tourism in developed versus developing countries", Tourism Economics, Vol. 17 No. 3, pp. 693-700.

Travel and Tourism Economic Impact (2017), available at: https://www.wttc.org/economic-impact/ countryanalysis/country-data/ (accessed 20 March 2021).

TRCTT (2013), "Thomson Reuters corporate responsibility ratings rating and ranking rules and methodologies", available at: http://financial.thomsonreuters.com/content/dam/openweb/documents/pdf/ tr-com-financial/methodology/corporate-responsibility-ratings.pdf (accessed 23 November 2021).

Turkay, M. (2017), "Heterogeneity across emerging market central bank reaction functions”, Central Bank Review, Vol. 17 No. 3, pp. 111-116.

Turner, L.W. and Witt, S.F. (2001), "Factors influencing demand for international tourism: tourism demand analysis using structural equation modelling, revisited", Tourism Economics, Vol. 7 No. 1, pp. 21-38.

UN (2004), "Who cares wins: connecting financial markets to a changing world", available at: https://www. scribd.com/fullscreen/16876740?access_key=key-16pe23pd759qallbnx2pv (accessed 23 November 2021).

UNCTAD (2013), "Sustainable tourism: contribution to economic growth and sustainable development: trade and development board", United Nations Conference on Trade and Development.

United Nations World Tourism Organization UNWTO (2003), "Djerba declaration on climate change and tourism", available at: http://www.travelmole.com/news_feature.php?id=97591. 
United Nations World Tourism Organization UNWTO (2019), available at: http://www2.unwto.org/en (accessed 3 March 2021).

United Nations World Tourism Organization UNWTO (2020), "International tourism highlights, 2020 edition”, doi: 10.18111/9789284422456 (accessed 20 April 2021).

United Nations World Tourism Organization UNWTO (2021), "2020: worst year in tourism history with 1 billion fewer international arrivals", available at: https://www.unwto.org/news/2020-worst-year-in-tourism-historywith-1-billion-fewer-international-arrivals (accessed 20 April 2021).

Usman, O., Bekun, F.V. and lke, G.N. (2020), "Democracy and tourism demand in European countries: does environmental performance matter?", Environmental Science and Pollution Research, Vol. 27, pp. 38353-38359.

Uusitalo, M. (2012), "Compensation committee composition and CEO compensation-Finnish evidence", Aalto University, School of Economics, Department of Finance, Rahoituksen laitos, available at: https:// aaltodoc.aalto.fi/handle/123456789/3905 (accessed 17 March 2021).

Uysal, M. and Crompton, J.L. (1985), "Deriving a relative price index for inclusion in international tourism demand estimation models", Journal of Travel Research, Vol. 24 No. 1, pp. 32-34.

Wagner, M. (2008), "The carbon Kuznets curve: a cloudy picture emitted by bad econometrics?", Resource and Energy Economics, Vol. 30 No. 3, pp. 388-408.

Walters, C.G. (1974), Consumer Behaviour: Theory and Practice, McGraw-Hill-Irwin, New Jersey.

Westerlund, J. (2007), "Testing for error correction in panel data", Oxford Bulletin of Economics and Statistics, Vol. 69 No. 6, pp. 709-748.

Witt, S.F. and Martin, C.A. (1987), "International tourism-demand models: inclusion of marketing variables", Tourism Management, Vol. 8 No. 1, pp. 33-40.

Wooldridge, J.M. (2010), Econometric Analysis of Cross Section and Panel Data, 2nd ed., MIT Press, Cambridge, Massachusetts.

World Economic Forum (2013), "The travel and tourism competitiveness report 2013", available at: https:// www.weforum.org/reports/travel-and-tourism-competitiveness-report-2013 (accessed 17 February 2021).

Yap, G. and Saha, S. (2013), "Do political instability, terrorism, and corruption have deterring effects on tourism development even in the presence of UNESCO heritage? A cross-country panel estimation", Tourism Analysis, Vol. 18 No. 5, pp. 587-599.

\section{Corresponding author}

Adewale Samuel Hassan can be contacted at: adewale706@gmail.com

For instructions on how to order reprints of this article, please visit our website: www.emeraldgrouppublishing.com/licensing/reprints.htm Or contact us for further details: permissions@emeraldinsight.com 